\title{
Fosinopril Sodium
}

National Cancer Institute

\section{Source}

National Cancer Institute. Fosinopril Sodium. NCI Thesaurus. Code C47542.

The sodium salt of fosinopril, a phosphinic acid-containing angiotensin-converting enzyme (ACE) inhibitor with antihypertensive activity. Fosinopril sodium is an ester prodrug that is hydrolysed by esterases to its active metabolite fosinoprilat. Fosinoprilat specifically and competitively inhibits ang iotensin-converting enzyme thereby decreasing the formation of the potent vasoconstrictor angiotensin II, resulting in diminished vasopressor activity. In addition, angiotensin II-mediated aldosterone secretion by adrenal cortex is decreased, which results in a decrease of sodium retention and an increase of serum potassium. ( $\mathrm{NCl05})$ 